\title{
COMER A PRÓPRIA CARNE: O MITO PESSOAL COMO DISPARADOR DO PROCESSO DE CRIAÇÃO CÊNICA
}

\section{Saulo Vinícius Almeida USP}

\section{Resumo}

Este artigo analisa o conceito de mito pessoal e seus desdobramentos em duas performances teatrais, Sebastian e Cura. Utiliza como base teórica os estudos do mito de Mircea Eliade, os estudos da psicologia profunda em sua relação com os conteúdos mitológicos de Carl Gustav Jung e seus continuadores e os escritos de Grotowski. Propõe a partir do mito pessoal a instauração de uma zona inconsciente de comunicação entre o performer e as testemunhas por via da infecção psíquica.

\section{Palavras-chave:}

Mitopoética; Arquétipos; Teatro ritual; Mito pessoal; Inconsciente.

A pesquisa que dá corpo ao presente artigo se iniciou no ano de 2016 e se estendeu até o final do ano de 2018, dentro do Departamento de Arte Dramática da Universidade Federal do Rio Grande do Sul- UFRGS, sob a orientação da Prof. ${ }^{a}$ Dr. ${ }^{a}$ Luciana Éboli, como Iniciação Científica e se desdobrou em minha monografia de conclusão de curso. O início da pesquisa se deu com a observação da Guarda de Moçambique de Nossa Senhora do Rosário na cidade de Oliveira Minas Gerais. Questões pertinentes ao corpo simbólico, ao tempo espiralar (MARTINS, 2003), ao mito encarnado, à relação de identificação pessoal e coletiva dos grupos com os mitos dançados e às energias transpessoais que atravessam os corpos dançantes se fizeram presentes ao fim do período de observação.

Como trabalhar cenicamente o mito e todas as questões que o atravessam com alunos-atores que não possuem nenhum vínculo cultural, religioso e/ou étnico com uma mitologia específica? Seria possível realizar em cena a atualização de um mito? Seria possível dar corpo às energias transpessoais? Tal questão é abordada por Grotowski (2011), que apontou a impossibilidade de um trabalho efetivo

\section{Abstract}

This article analyzes the concept of personal myth and its ramifications in two theatrical performances, Sebastian and Cura. It uses as theoretical base the studies of the myth of Mircea Eliade, the studies of analytical psychology in its relation with the mythological contents of Carl Gustav Jung and its followers and the writings of Grotowski. It proposes from the personal myth the establishment of an unconscious zone of communication between the performer and the witnesses through the psychic infection.

\section{Keywords:}

Mythopoetic; Archetypes; Ritual theater; Personal mith; Unconscious.

com o mito sem que existisse um terreno comum de crenças. $O$ encenador-pedagogo afirmou que a relação entre o espectador e o mito encenado se estabelecia cada vez mais de forma pessoal, em um contexto no qual a crença se torna assunto de convicção intelectual.

Como resposta a essa impossibilidade de identificação com o mito, propõe que ao invés da tentativa de identificação com o mito, o ator realize um confronto com o mesmo, encarnando-o para então perceber as relatividades acerca de nossos problemas (os quais atravessariam a narrativa do mito) e a sua conexão com as raízes. Ao tocar as camadas mais íntimas de si e as expôlas, a máscara da vida cairia e a violação desse organismo vivo exposto transportaria a todos para uma situação mítica.

Em Campbell (1990), encontramos uma reflexão próxima. Para o mesmo, o processo de globalização e a pluralidade cultural gerada por esse resultam em uma crescente desmitologização da sociedade. Assim como Carl G. Jung, Mircea Eliade (2016, p. 73) assevera que 0 inconsciente possui estrutura 


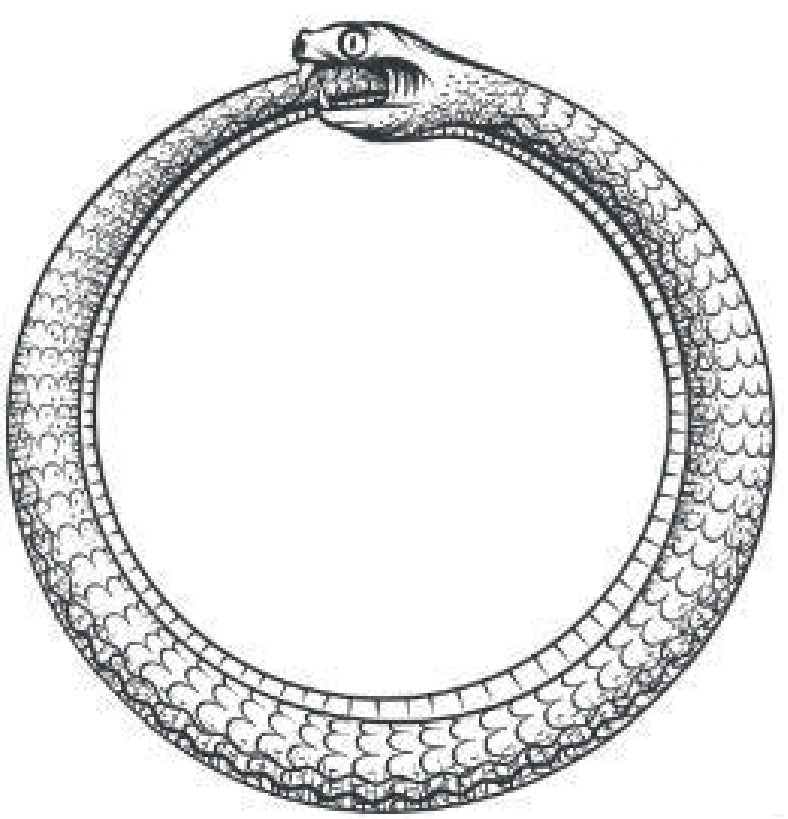

Figura 1 - Ouroboros.

mitológica e a partir dessa prerrogativa, ele resolve o problema da identificação do homem moderno com o mito.

Eis a razão por que o inconsciente apresenta a estrutura de uma mitologia privada. Pode-se ir mais longe ainda e afirmar que não somente o inconsciente é "mitológico", mas também que alguns de seus conteúdos estão carregados de valores cósmicos; em outros termos, que eles refletem as modalidades, os processos e dos destinos da vida e da matéria vivente. Pode-se mesmo dizer que o único contato real do homem moderno com a sacralidade cósmica é efetuado pelo inconsciente, quer se trate de seus sonhos e de sua vida imaginária, quer das criações que surgem do inconsciente (poesia, jogos, espetáculos, etc).

A partir desta perspectiva levantada pro Eliade e dos estudos de Carl G. Jung acerca da estrutura da psique, me valho do conceito de mitologia pessoal proposto por ele (e estudado por David Feinstein e Stanley Krippner (1997) dentro da psicologia e por Renato Cohen (1998) e Luciana Lyra $(2005,2011)$ na práxis cênica), tendo como hipótese que a partir deste e dos conteúdos inconscientes acessados a partir do mesmo tornasse possível instaurar na cena um acontecimento mítico, sendo este de caráter real e sagrado.

Para os pesquisadores David Feinstein e Stanley Krippner (1997), a mitologia pessoal é um sistema de mitos pessoais que oriente o indivíduo e organiza o seu sentido de realidade. Dentro da mitologia pessoal há o mito pessoal que é o conjunto de imagens, sentimentos e crenças deste indivíduo que é organizado em torno de uma temática central de cunho mitológico. Durante a pesquisa, utilizei dois métodos de acesso a essa mitologia pessoal. O primeiro se deu com o confronto ao que Luciana Lyra (2005) denomina de mito guia e o segundo método, desvela a mitologia pessoal e o mito guia a partir da experiência instaurada no confronto com o mitologema proposto pela estrutura de encenação.

A figura mitológica Ouroboros (figura 1) é uma serpente que come a sua própria cauda. Formasse um círculo que em sua significação abarca os grandes ciclos da vida, o tempo, a morte, a ressurreição, a renovação. Nos estudos búdicos, o ouroboros aparece como símbolo do olhar para si e é neste sentido que compreendo o mito pessoal. A partir de um olhar para si, devorasse em um movimento de autoantropofagia, em que o indivíduo alimentasse de suas memórias e de seu corpo para chegar até a sua essência. É de um ator autoantropofágico em uma cena ourobórica que se alimenta de sua concretude e de sua virtualidade, tendo no acontecimento a razão única de seu fazer, que se tratam os dois experimentos cênicos que abordarei e analisarei brevemente.

\section{1 - SEBASTIAN E O MITO DE SÃO SEBASTIÃO}

Durante o ano de 2017, construí o espetáculo Sebastian, no qual assino a direção. Esse processo de criação se deu a partir do mito guia de São Sebastião, o qual o ator compreendeu que por diversas questões e experiências acausais constitui sua identidade e atravessa a forma como o mesmo percebe o mundo. São Sebastião é um mártir da mitologia católica que segundo as narrativas religiosas teria sido assassinado em 20 de janeiro de 288. Ainda jovem ingressou na Guarda Pretoriana, sendo brevemente elevado ao cargo de comandante de sua unidade militar. Utilizou-se então deste posto para ter acesso aos calabouços e consolar os crentes cristãos. S. Sebastião ocultou sua fé de seus superiores na Guarda. O imperador ao descobrir tal fato e também as ações que Sebastião cometia em nome de Cristo ordenou que o mesmo fosse sacrificado. O mártir católico teve seu corpo amarrado e flechado (SALOMÃO, 2008). 


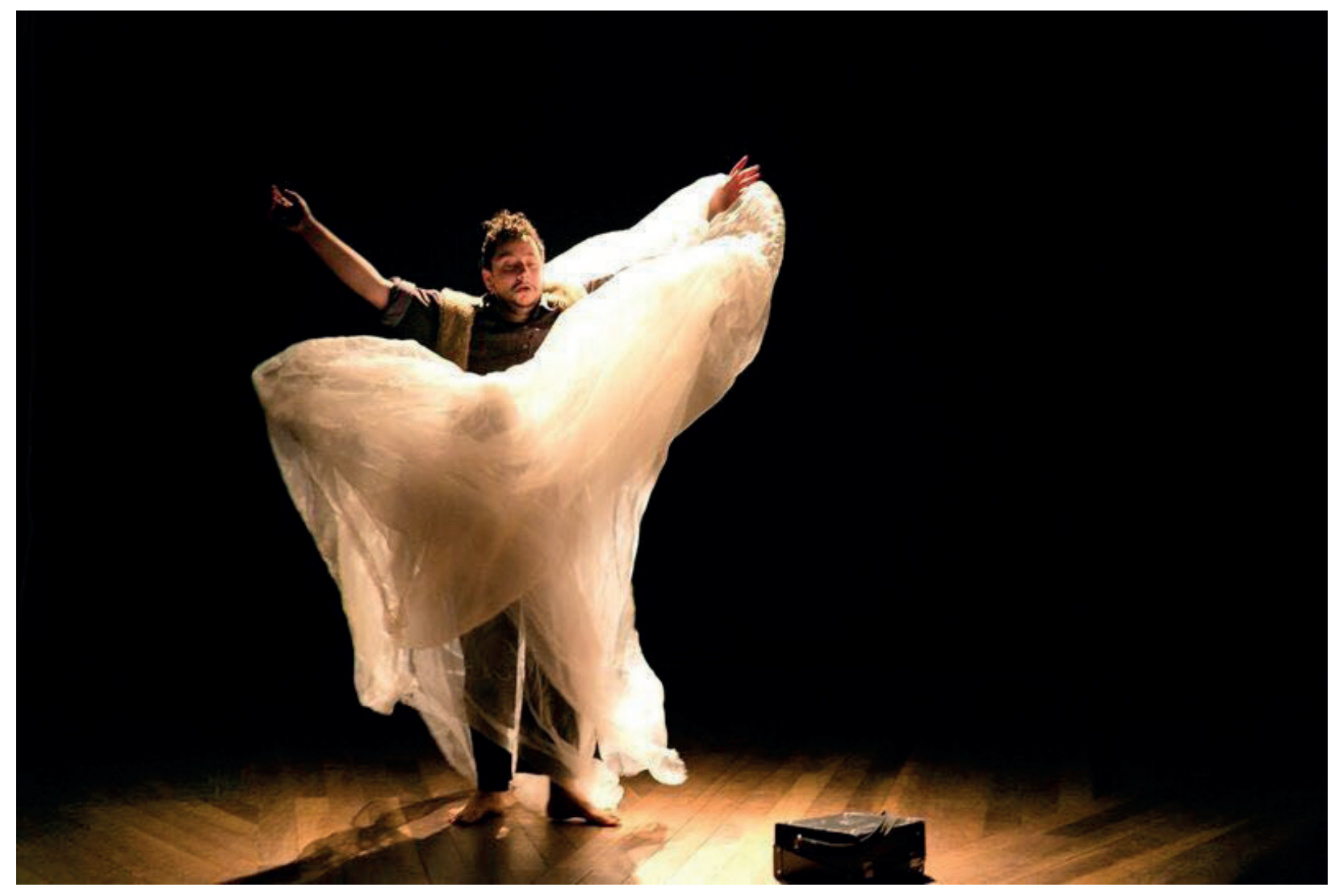

Figura 2 - Espetáculo Sebastian I.

O corpo desfalecido foi entregue a uma cristã de nome Irene, a qual verificou que o mesmo ainda estava vivo. Após alguns dias, estando curado, retorna ao palácio e desafia o imperador ordenando que se arrependesse de seus atos contra os cristãos. O imperador, por sua vez, ordena que Sebastião fosse espancado até a morte e que seu corpo fosse tratado como um dejeto após o seu falecimento e atirado numa fossa. Com o passar dos séculos, a figura de São Sebastião se tornou o padroeiro dos gays, assumindo nas suas representações um aspecto erotizado. Na umbanda, é tido como sincretismo do Orixá Oxossi. (SALOMÃO, 2008)

A tessitura cênica se construiu a partir de duas camadas distintas. Na primeira, realizou-se um aprofundamento no trabalho com o mito por parte do performer por vias da irracionalidade e do inconsciente. Na outra camada, por meio de uma sobreposição de elementos cênicos, criou-se uma estrutura textual de encenação.

O processo de direção se valeu da estrutura básica de um ritual de sacrifício (MAUSS; HUBERT, 2005), de modo que para cada momento deste ritual foi proposto ao ator que este construísse uma resposta corpórea a partir da relação que se estabelecia entre suas experiências de vida e alguma célula significante do seu mito guia. Em um primeiro momento, os resultados cênicos se davam com características do que Jung (2013b) entendeu como gênero introvertido. Para o autor existem dois movimentos psicológicos nos quais se constituem os processos de criação artística, o introvertido e o extrovertido. "O gênero introvertido caracteriza-se pela afirmativa do sujeito e de suas intenções e finalidades conscientes em oposição às solicitações do objeto; em contrapartida, o gênero extrovertido é caracterizado pela subordinação do sujeito às solicitações do objeto" (JUNG, 2013b, p. 74).

Jung (2013b) entende a obra de arte como um processo que de certo modo é autônomo ao sujeito. Para ilustrar essa questão, ele propõe a imagem de uma planta e o solo na qual ela se encontra. A arte, assim como a planta, possui vida e seus próprios processos que são alimentados e possibilitados pelo solo, ou seja, pelo artista. Quando este, o artista, trabalha de 


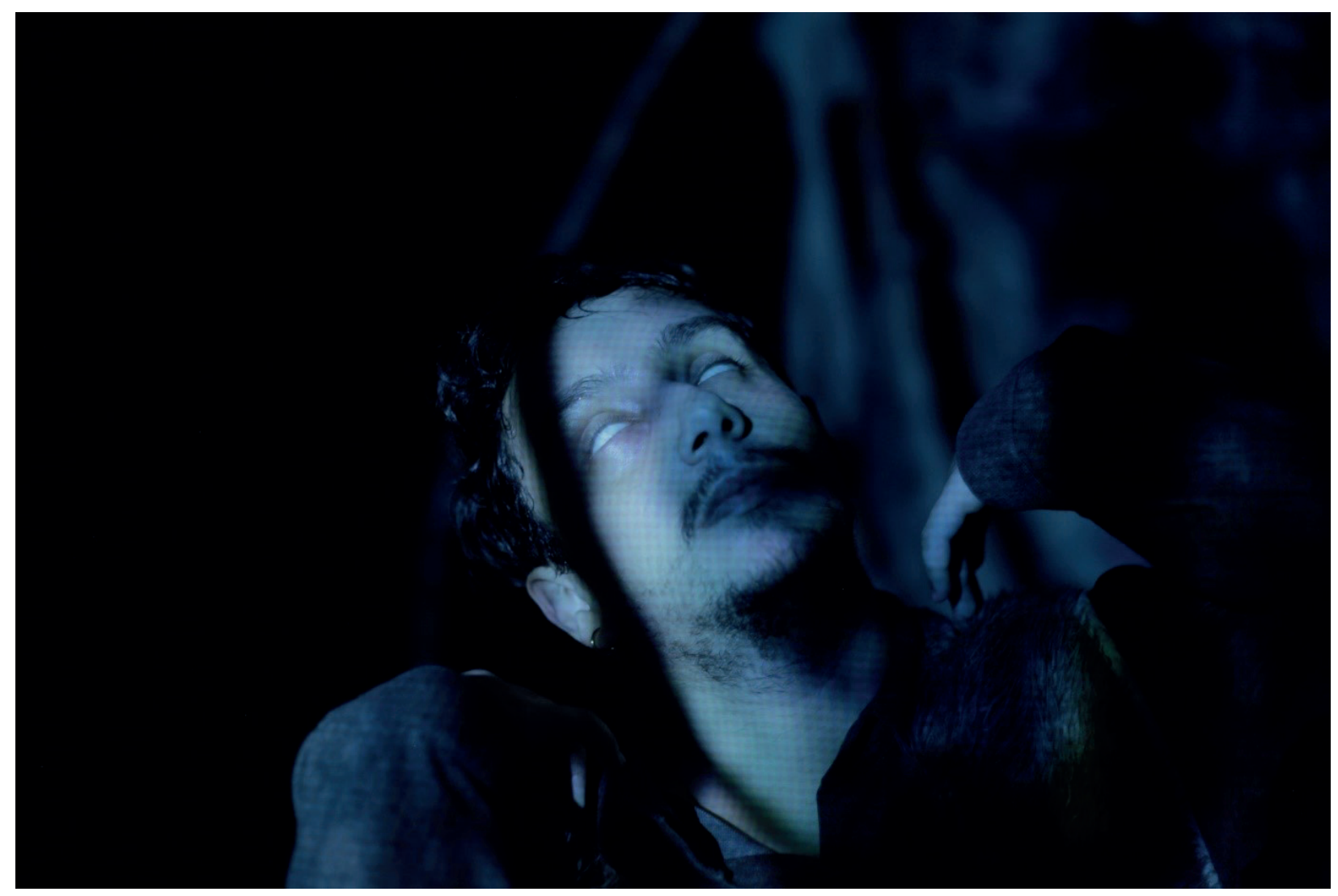

Figura 3 - Espetáculo Sebastian II.

modo introspectivo, esperasse uma obra que não ultrapasse os limites do intencionado, do signo calculado.

Grotowski (2010, 2011), sobre seu processo de criação, faz apontamentos que compreendo como uma característica de criação extrovertida, a saber: "Percebi que a montagem levou à consciência ao invés de ser o produto da consciência" (GROTOWSKI, 2011, p. 15) ou quando discutindo sobre o encontro gerado pelo desvelamento do mistério humano diz que "Talvez não seja o único caminho rumo ao teatro, mas considero que nesse caminho somos muito mais devorados por aquilo que fazemos" (GROTOWSKI, 2010, p. 181).

A partir desta prática e aceitando a premissa de que a esfera mitológica da psique se encontra além da zona consciente, no que Jung (2000b) denomina como inconsciente coletivo, nós buscamos mecanismos para ultrapassar a criação introvertida e tornar o corpo mais permeável para o fluxo de imagens de caráter arquetípico. Segundo Mircea Eliade, "o inconsciente apresenta a estrutura de uma mitologia privada. Pode-se ir mais longe ainda e afirmar que não somente o inconsciente é "mitológico", mas também que alguns de seus conteúdos estão carregados de valores cósmicos" (2016, p. 73).

Trabalhamos com o intuito de realizar um rebaixamento do consciente, em consonância com a psicóloga e cientista da religião Lilian Wurzba (2011) que em seu estudo sobre as relações entre a dança e o sagrado aponta que a partir do rebaixamento da consciência, ocorre uma diminuição no sentido de orientação e isso permite que conteúdos do inconsciente ascendam a zonas conscientes do indivíduo. Jung (2014, p. 29) propõe que o contrário também é verdadeiro:

Os arquétipos são fatores formais responsáveis pela organização dos processos psíquicos inconscientes: são os patternsofbehaviour (padrões de comportamento). Ao mesmo tempo, os arquétipos têm uma "carga específica": desenvolvem efeitos numinosos que se expressam como afetos. 0 afeto produz um abaissement de niveau mental (baixa do nível mental) parcial, porque, justamente na mesma medida em que eleva um determinado conteúdo a um grau supranormal de luminosidade, retira também tal quantidade de energia de outros conteúdos possíveis da consciência, a ponto que esses se tornam obscuros e inconscientes. 


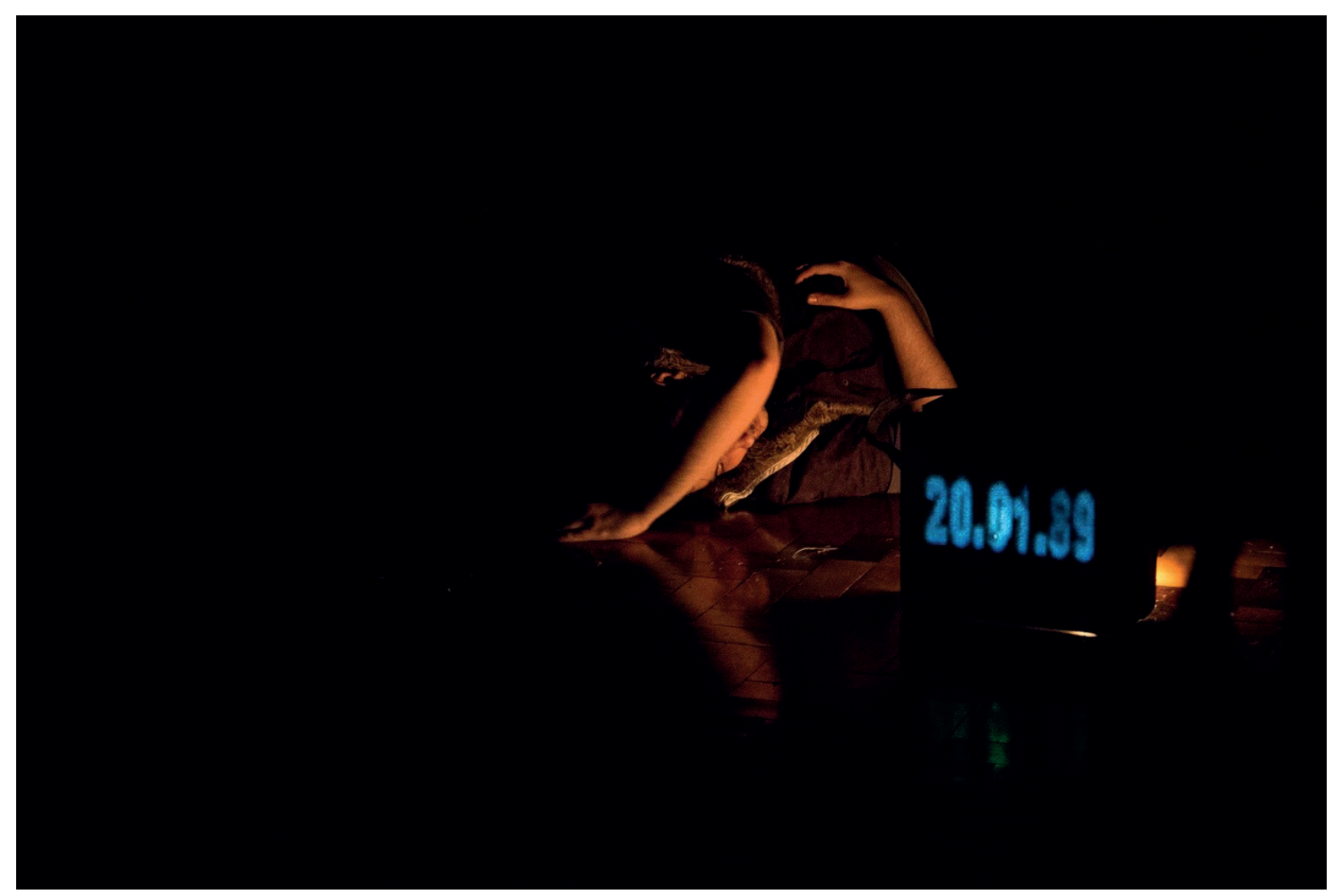

Figura 4 - Espetáculo Sebastian III.

Esse processo ocorreu em sala de ensaio a partir de exercícios energéticos ligados a poética dos elementos materiais de Bachelard (1989), de práticas de exaustão e pela dança pessoal, a qual ocorria durante várias horas seguidas e neste processo flertou com os princípios e a estética do Butoh. Para o diretor Ushio Amagatsu, "o butoh é mais uma tentativa de articular a linguagem corporal do que de transmitir alguma ideia e visa proporcionar a cada espectador uma viagem particular ao seu mundo interior" (apud BAIOCCHI, 1995, p.17).

Esta fase do trabalho passou por dois momentos distintos, um que se relaciona com lembranças e outro que se afastou das questões de cunho extremamente pessoais e se materializou a partir de imagens simbólicas coletivas. Essas duas fases por muitas vezes ocorriam seguidamente, como elos seguidos de uma corrente. O exercício que se iniciava nas sensações física desembocava na experiência do afeto, para então abrir fendas para a constelação de lembranças e para as experiências que compreendo como de caráter arquetípico.
Jung (2000a) acerca das lembranças aponta que aquelas que estão perdidas do espectro consciente se encontram, junto com os conteúdos reprimidos de forma mais ou menos intencional no que ele domina de inconsciente pessoal. Durante os laboratórios percebemos diversas camadas de lembranças que retornavam à pele. Memórias próximas que surgiam como um reviver-se de características causais, ou seja, uma lembrança gerava o elo para o surgimento de outra. Em outra camada que entendemos como mais profunda, surgiam, rompendo com essa sequência de lembranças iniciais, vivências e sentimentos esquecidos que quando atualizados no corpo geraram outra qualidade de presença e transformação do tônus e das dinâmicas de movimento.

Sendo a biologia, a cultura e a história pessoal partes do que se entende como mitologia pessoal é compreensível esse tipo de experiência durante o processo. Ocorre que tais experiências não são suficientes para justificar a utilização do mito pessoal como realmente um processo numinoso de construção cênica ou mesmo como sendo um processo distinto do que se compreende como 


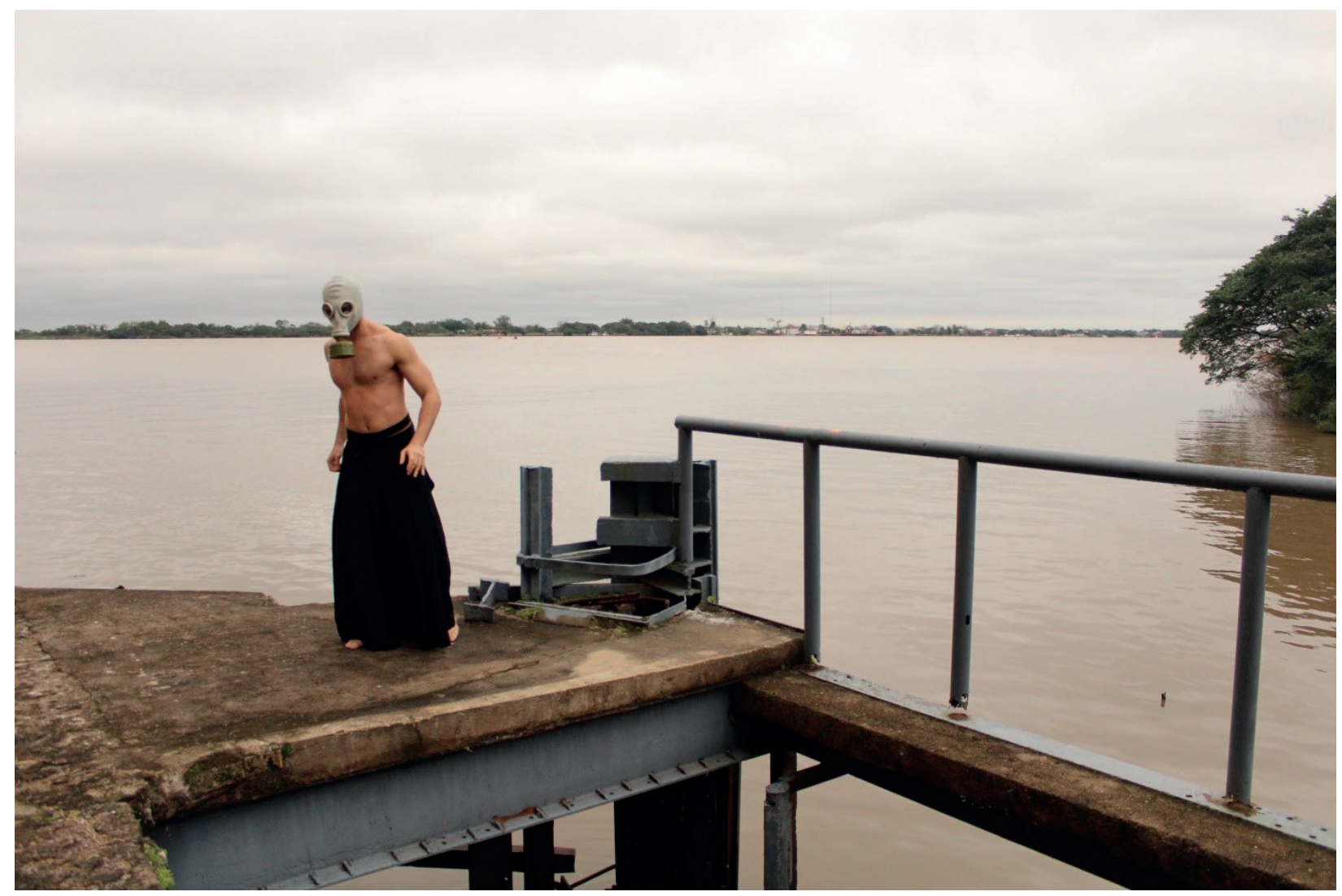

Figura 5 - Espetáculo Cura I.

criação auto narrativa ou biodrama. Contudo, a insistência nesses exercícios e a fricção destes com os estímulos baseados no mito guia geraram ao longo do tempo momentos que compreendo como de caráter arquetípico, ou seja, momentos nos quais imagens humanas universais e originárias com caráter numinoso eram acessadas.

As lembranças, quando surgiam se atualizando nesse corpo em estado de trabalho modificavam imediatamente a qualidade da presença do ator, assim como as dinâmicas do seu corpo no espaço. Nas situações que compreendi como de caráter arquetípico, inicialmente, podiamse observar os mesmos efeitos de quando surgiam as lembranças, contudo, o corpo se comportava de maneira distinta, assumindo no seu conjunto de movimentos a construção de figuras ou movimentos de caráter simbólico. "Afora as recordações pessoais, existem, em cada indivíduo, as grandes imagens 'primordiais' [...], ou seja, a aptidão hereditária da imaginação humana de ser como era nos primórdios" (JUNG, 2015, p. 39). Acompanhando essa modificação de dinâmica concreta do ator, houve também modificações na percepção tempo-espacial, seja por parte do ator, seja por parte das pessoas que testemunharam o acontecimento.

\section{2 - CURA, O MITOLOGEMA DA VIAGEM NOTURNA SUBMARINA}

Durante o ano de 2018, construí na função de ator o espetáculo Cura, com o intuito inicial de experimentar no corpo as percepções que obtive enquanto diretor. Acho interessante frisar que mesmo na distância que o ato de dirigir propicia com relação à experiência cênica, meu corpo foi sempre atravessado, tomado, transformado com o acontecimento possibilitado e presentificado no instante pelo corpo do ator. Afinal, como o próprio Jung aponta, "ninguém mexe com fogo ou veneno sem ser atingido em algum ponto vulnerável" (2015, p. 116).

No espetáculo Cura, proponho não utilizar o mito guia como estratégia para a experiência numinosa, mas sim utilizar de um mitologema e a partir da estrutura propiciada pelo mesmo, experienciar o trabalho da mitologia pessoal. O mitologema, segundo James Hollis (2005), é um elemento ou tema isolado em qualquer mito. 


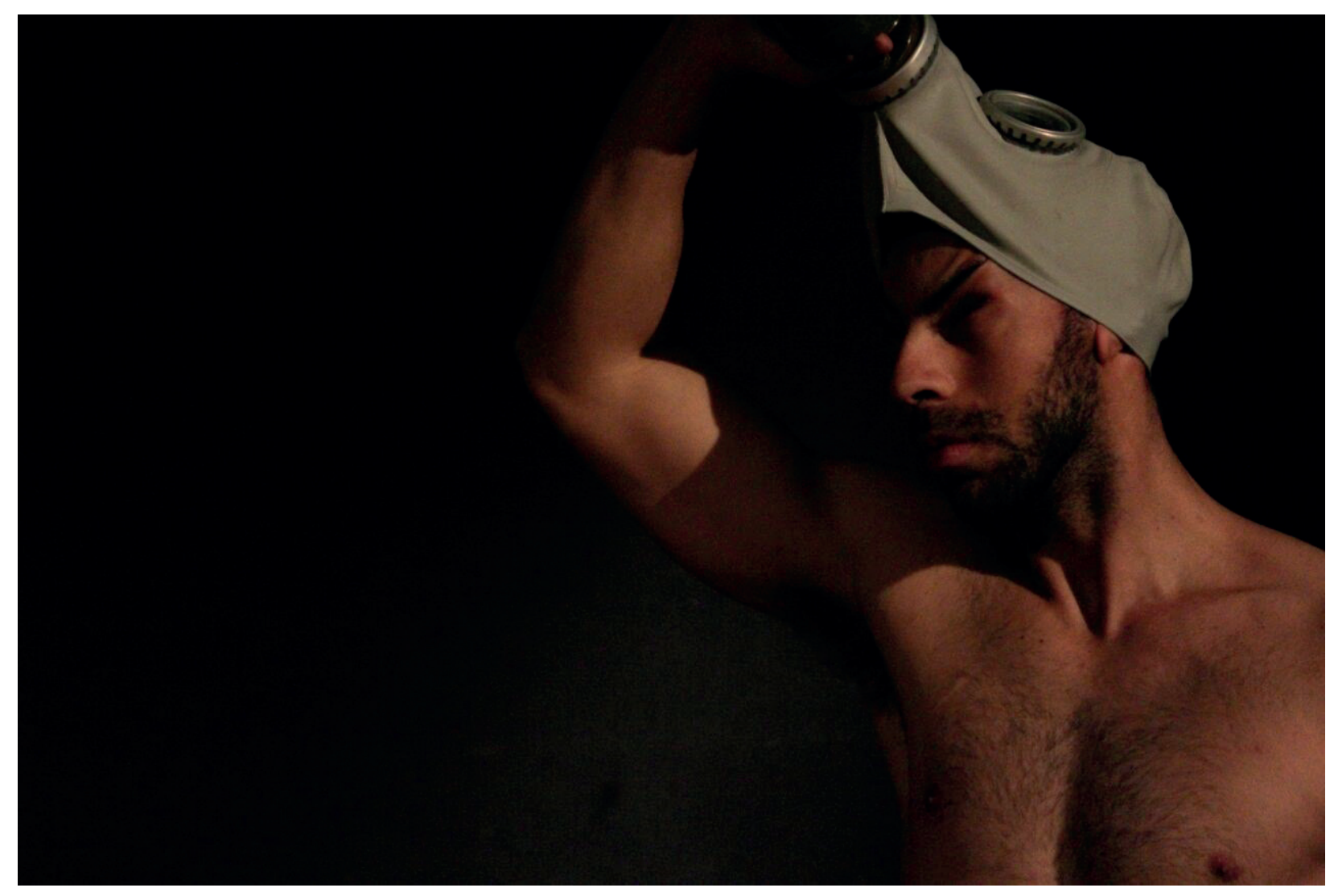

Figura 6 - Espetáculo Cura II.

A Viagem Noturna Submarina é a estrutura básica que alicerça inúmeros mitos. Nela há a morte do herói, o seu mergulho na escuridão e seu retorno transformado. Campbell (1990) nos dá o exemplo do mito de Jonas e a baleia, neste, Jonas é engolido e na barriga da baleia é levado ao abismo, para então ressuscitar. Realizando uma leitura simbólica deste tema mítico, o autor explica que a água, assim como em praticamente todos os estudos de simbologia nos quais podemos encontrar a mesma compreensão, representa o inconsciente e a baleia, psicologicamente, é o poder de vida contido neste inconsciente que por ter dominado a consciência necessita ser controlada e superada.

O primeiro estágio desse tema mítico, segundo Joseph Campbell (1990), é aquele em que o herói abandona a família e se encontra a beira das águas nas quais o peixe, a baleia ou o monstro vem a seu encontro. Num segundo estágio, já dentro da barriga, o herói se depara com uma energia de caráter inconsciente que não é capaz de controlar e disso se derivam como consequências as provações que como em uma jornada o mesmo terá que ultrapassar para em um terceiro estágio renascer a uma nova vida.
Jung (2012a, p. 350) faz uma leitura deste mitologema que corrobora com a apontada por Campbell. Para o autor, "a obscuridade e a profundeza do mar significam apenas o estado inconsciente de um conteúdo que é projetado de modo invisível" e a saída do herói do monstro submarino equivale ao reestabelecimento da vida e a ressurreição da morte. Para o autor, o que leva o herói em um mito a essa descida as profundezas é a possibilidade de se encontrar um tesouro, seja este uma virgem ou a vitória da vida sobre a morte. Esse mergulho é o mergulho profundo em si mesmo, o mergulho ao Hades.

Esta estrutura pode ser identificada em alguns sonhos e em hinos citados por Jung (2000b) no decorrer de sua obra:

Este sonho mostra-nos o simbolismo natural. O sonhador desce à sua própria profundeza, e o caminho o leva à água misteriosa. Ocorre então o milagre da piscina de Betesda. Um anjo desce e toca a água que adquire então poder curativo. No sonho, é o vento, o pneuma, que sopra onde quer. É necessário que o homem desça até a água, a fim de que se produza o milagre da vivificação (p. 27-28) 
No hino gnóstico à alma, o Filho é enviado pelos pais à procura da pérola perdida que caíra da coroa real do Pai. Ela jaz no fundo do poço profundo, guardada por um dragão, na terra dos egípcios - mundo e concupiscência e embriaguez com todas as suas riquezas físicas e espirituais. O filho e herdeiro parte à procura da jóia, e se esquece de si mesmo e de sua tarefa na orgia dos prazeres mundanos dos egípcios, até que uma carta do pai o lembra de seu dever. Ele põe-se então a caminho em direção à água e mergulha na profundeza sombria do poço, em cujo fundo encontra a pérola, para oferece-la então à suprema divindade (p.28)

Durante o processo de criação deste espetáculo, que se valeu de exercícios próximos aos empregados na construção do espetáculo Sebastian, a imagem de uma ave surgiu no processo de criação da penúltima estrutura cênica e tornou-se um elemento de grande importância cênica. Este símbolo não estava de acordo com os percursos que havíamos traçado até então e muito menos com o mitologema em questão. Contudo, deparei-me com outra versão destra estrutura mítica, apresentada por Jung (2013a) em seu estudo sobre a energia psíquica. Neste estudo, o pesquisador aponta que o sair do corpo da baleia se dá com a ajuda de um pássaro que é simultaneamente o nascer do sol.

Temos neste acontecimento do surgimento do pássaro a ilustração de um caso de sincronicidade.

A sincronicidade, portanto, significa, em primeiro lugar, a simultaneidade de um estado psíquico com um ou vários acontecimentos que aparecem como paralelos significativos de um estado subjetivo momentâneo e, em certas circunstâncias, também vice-versa(JUNG, 2014, p. 35).

Um conteúdo inesperado que está ligado direta ou indiretamente a um acontecimento objetivo exterior, coincide com o estado psíquico ordinário: é isto o que chamo de sincronicidade, e sou da opinião que se trata exatamente da mesma categoria de eventos, não importante que sua objetividade apareça separada da minha consciência no tempo e no espaço (JUNG, 2014 , p. 39, grifo do autor).

O artista-pesquisador e professor Renato Cohen (1998, p. 70) utilizou a noção de sincronicidade em sua tese de doutoramento para entender acontecimentos presentes em processos de criação que tinham como linha de trabalho a irracionalidade. Este conceito levanta a questão da relação tempo/ espaço na práxis cênica. Cohen compreende que no trabalho com o mito e no âmbito da irracionalidade há um deslocamento da lógica logo temporal para uma lógica espacial, uma lógica do mythos.
Trabalho de fundo, subliminar, dimensionando o atuante em outra sintonia, por processos de imersão (física, psíquica, temporal), através de trabalhos de atenção, estranhamento, alteração de dinâmicas, possibilitando a emergência de conteúdos internos, a alternância de referenciais e, principalmente, a criação de um campo de sincronicidades.

A sincronicidade, conforme estudada por Jung (2014, p. 28-29) é uma relativização do tempo e do espaço que se comportam com características elásticas em relação à psique.

Nas experiências com o tempo e o espaço, respectivamente, esses dois fatores reduzem-se mais ou menos a zero, como se o espaço e o tempo dependessem de situações psíquicas, ou como se existissem por si mesmos e fossem "produzidos" pela consciência. Na concepção original do homem (isto é, entre os primitivos), o espaço e o tempo são coisas sumamente duvidosas.

Segundo Wurzba, quando "os processos racionais conscientes são arrebatados pela irracionalidade inconsciente, ocorre uma relativização do ego e, consequentemente, uma relativização também das categorias de tempo e espaço" (2011, p. 93). A autora aponta em sua pesquisa que embora se possa dividir o tempo real em quatro categorias, o tempo cinético, o tempo rítmico, o tempo programado de execução e o tempo narrativo, a experiência da dança propicia que o homem se desloque do tempo e penetre o vazio. Fora do tempo, ele abandona o seu espaço e chega ao infinito. Os movimentos então deixariam de ser realizados por essas pessoas e seriam realizados então por forças transpessoais (WURZBA, 2011).

O corpo se torna, nesse contexto, tanto canal pelo qual o material contido no inconsciente coletivo se externaliza quanto matéria na qual a energia desse processo age. Jung (2013a) em seu estudo sobre a energia psíquica, diz que existe a possibilidade de essa estar ligada intimamente ao processo físico, podendo por meio de processos fisiológicos, transformar-se em energias físicas. O corpo se torna um tradutor e o discurso do inconsciente no mundo, sendo a linguagem simbólica o vernáculo.

A viagem no mundo ou submundo inconsciente da psique no processo de criação se deu também no universo onírico dos sonhos. Um dos fatores constituintes da sincronicidade (JUNG, 2014,p. 41) é a transposição de imagens da inconsciência para a consciência pela via indireta dos sonhos, associações ou premonições. Dentre os casos em 


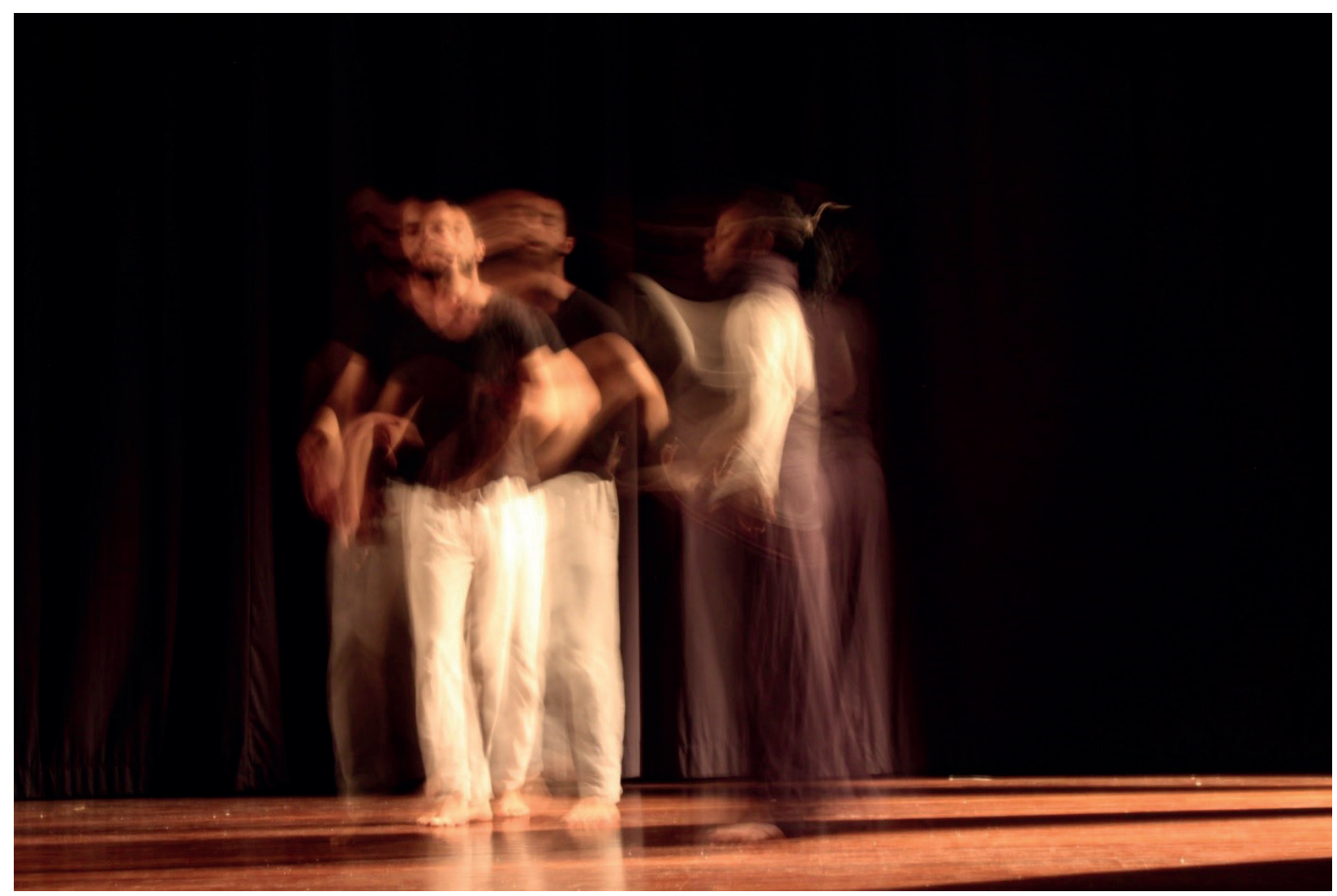

Figura 7 - Ensaio do espetáculo Cura.

que isto ocorreu neste processo, ressalto dois sonhos em que conteúdos referentes ao processo cênico apareceram. Os sonhos envolviam jogo de búzios, tarot, baralho cigano e uma professora do departamento com a qual tive praticamente três aulas durante quatro anos de curso.

Após o relato dos conteúdos destes sonhos à professora em questão, obtive como resposta que inúmeros elementos que os constituíam equivaliam a realidades de sua vida, as quais eu não teria como ter acesso e conhecimento. Com o passar do tempo, percebi que várias informações contidas nos sonhos, como por exemplo, uma modificação de elementos materiais que apareceu nas cartas de tarot, começou a ocorrer na criação cênica. Novamente estava defronte a características de um processo extrovertido de criação. A obra se fazia por si gerando apenas uma ilusão de controle por minha parte consciente.

As categorias de análises causais tornam-se inúteis para os processos que explodem com a lógica racional da criação. O sentido, o texto, o ponto de partida e de chegada não possuem importância. No universo do mito a narrativa não é do logos. "Na física moderna, parece, por vezes, que o efeito ocorreu antes da causa e, portanto, os físicos tentam darIhe uma viravolta e dizer que ainda podemos chamar isso de causal" (FRANZ, 1993, p.8).

\subsection{1 - SÍSIFO - A ECLOSÃO DO MITO PESSOAL}

O mitologema se tornou um caminho a ser seguido na construção do exercício cênico, na instauração do acontecimento. Em momento algum houve o intuito de se criar uma narrativa transformando o acontecimento em uma história ou mesmo a estruturação de personagens ou personas. A proposta era que o ator, no caso eu, percorresse os fluxos de energia identificados na estrutura base e que o corpo se tornasse um espaço de mediação entre os universos concretos e imaginários que coexistem e se atravessam e constroem-se no ato presente.

Ao longo dos ensaios, identifiquei uma série de sinais que me trouxeram a consciência o mito de Sísifo. Utilizo o termo sinais no sentido empregado por Erna van de Winckel (1985) que os compreende como "subdivisões, ramificações dos símbolos 


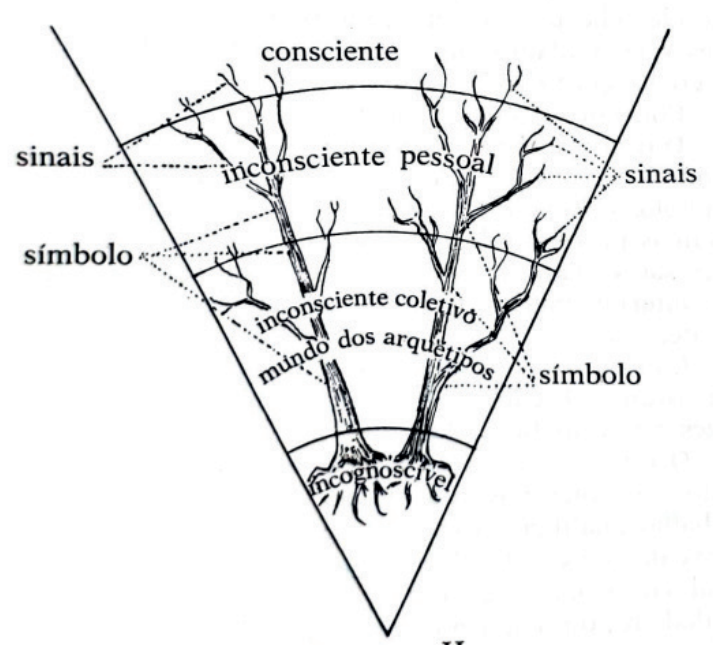

Figura 8 - Esquema de símbolos e sinais proposto por Winckel.

primordiais" e que "frequentemente são muito numerosos e às vezes parecem bem afastados de seu sentido primeiro" (p. 32).

Este mito narra a experiência de sofrimento de Sísifo que devido a um castigo dos deuses, passa a eternidade em um trabalho extenuante e repetitivo de arrastar um bloco imenso com as mãos até o cume de um morro e quando finalmente chegava próximo à realização da tarefa, a pedra, em função de seu peso e da gravidade, rolava para baixo e nisso reiniciava-se a tarefa (KAST, 2017). Vários elementos desta narrativa passaram aos poucos a tornarem-se presentes, desde os elementos materiais contidos no mito, até motivos físicos, energias, tensões corpóreas, desistências em meio ao processo e a incapacidade de se formular a cena final.

É de se esperar que a cena elaborada a partir de exercícios de criação pautados na irracionalidade (que tomam práticas como desequilíbrio, exaustão, hiperventilação como mecanismos disparadores do processo criativo) desvincule-se das estruturas narrativas e possibilitem a eclosão da vida em seu caráter mítico. Levando-se em consideração que o mito pessoal é "a representação dramática da nossa vida instintiva mais profunda... passível de inúmeras configurações, da quais dependem todas opiniões e atitudes particulares" (FEINSTEIN; KRIPPNER, 1997, p. 35) e que

sua mitologia é o produto de quatro fontes interatuantes. A biologia, a cultura e a história pessoal são as mais óbvias. Uma quarta fonte originasse de experiências transcendentes - aqueles episódios, percepções interiores, sonhos e visões cuja qualidade numinosa parece expandir nossa compreensão e inspirar nosso comportamento (p. 179-180).

Renato Cohen (1998, p. 66), sobre as experiências em terreno mítico no fazer teatral diz que "a cena mítica, momento de permeação ou de reapresentação do fenômeno primeiro, investe-se pelo seu caráter direto com a experiência, plena de visibilidade e sensação, de uma potência superior à narrativas e relatos".

Este caráter direto com a experiência se possibilita , segundo o autor, a partir de uma ampliação da presença, seguida da inteireza, adensamento e exacerbação por parte do atuante na ação presente. Esse conjunto de atitudes "diminuem as demandas energéticas para atender às vicissitudes do cotidiano e o participante passa a operar mais pleno, tendo acesso, principalmente, à sua mente subliminar, não objetiva" (COHEN, 1998, p. 67). Essa inteireza rompe, em minha perspectiva, com as distinções interno/externo, tornando assim o corpo vivente, o mito em ação. Independente de assumir ou não o mito guia como gatilho de criação, não há como desvincular-me de minha existência e minha constituição psíquica e desta forma, a mitologia pessoal sempre se fará presente em minhas respostas aos estímulos externos e quanto mais integro estiver, mas visível se tornará a dimensão arquetípica, confluindo para o que a psicóloga e professora Rosa Maria Farah chama de vivência poética arquetípica.

\section{2 - A CENA MITOPOÉTICA}

Na zona liminar da iluminação do conteúdo inconsciente para o espaço da consciência, ocorre o que Jung denomina como função transcendente da psique e que o médico brasileiro Walter Boechat (2016) em uma continuidade dos estudos junguianos identifica como função mitopoética da psique ou simplesmente função mitopoética.

Por "função transcendente" não se deve entender algo de misterioso e por assim dizer de suprassensível ou metafísico, mas uma função que, por sua natureza, pode-se comparar com uma função matemática de igual denominação, e é uma função de números reais e imaginários. A função psicológica e "transcendente" resulta da união dos conteúdos conscientes e inconscientes (JUNG, 2000a, p.13)

A discussão dessa função justificasse por possibilitar que presumíveis experiências de caráter 


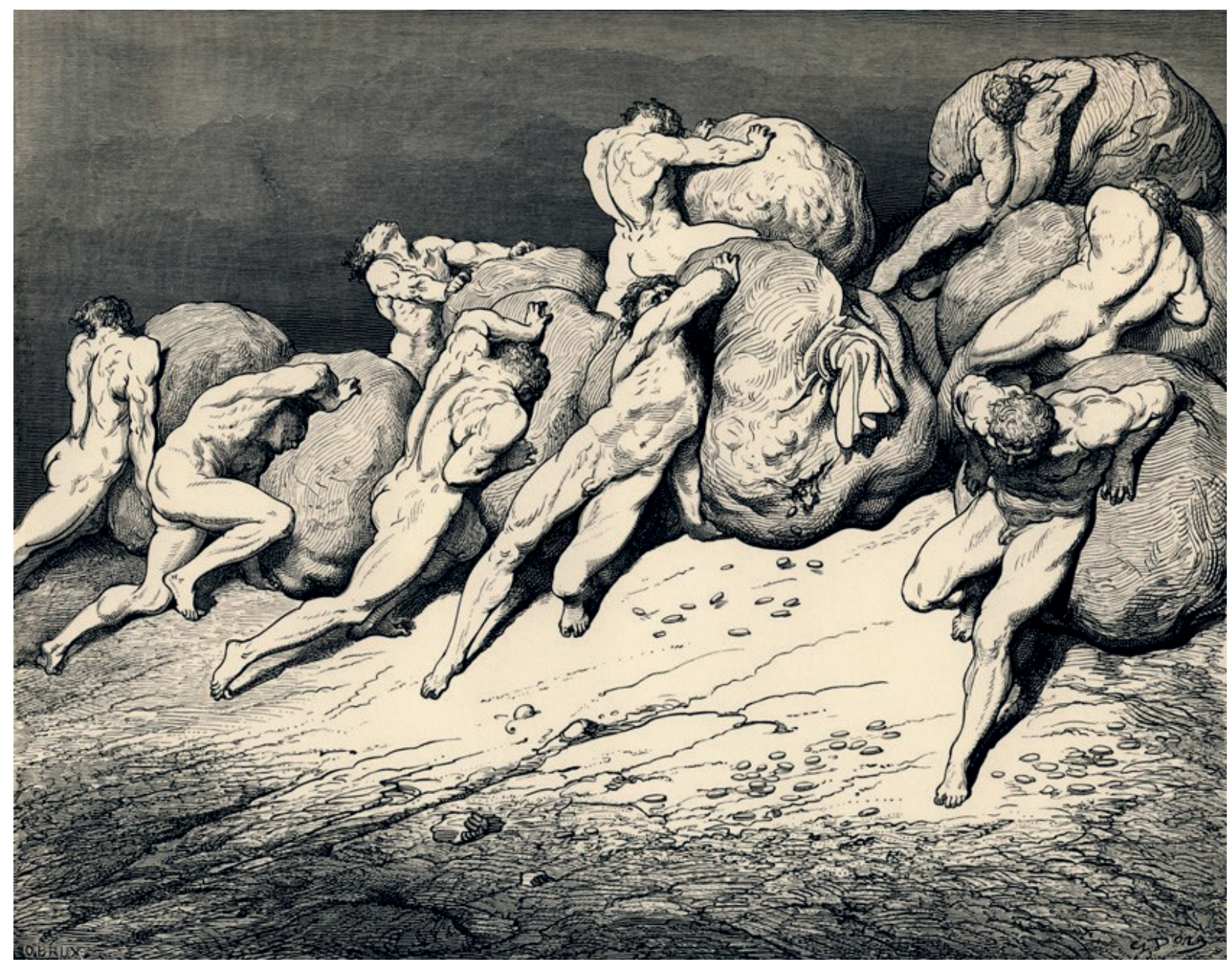

Figura 9 - Sísifo empurrando sua rocha.

primordial do não eu da alma atinjam o espaço da consciência e desse modo o espaço concreto externo ao sujeito, se tornando assim caminho para um experimento performático. Além disto, o arquétipo quando aparece, seja em sonho ou na vida, ele traz, segundo Jung (2015), uma força que confere a este um caráter numinoso.

Antes de adentrar a discussão acerca deste tema, friso que um conceito embora tente apreender a realidade, não passa de um nome e como tal não é possível ser experienciado. Faz-se necessário, então, que se investigue na vivência o conjunto dinâmico de relações às quais a conceituação tenta dar conta abarcando-o em um nome. O conhecimento e a compreensão se possibilitam no contato, no contágio com a ideia concretizada que se abriu pela experiência.

A experiência da vida dita concreta é uma experiência psíquica. Os sentimentos, os pensamentos são formados a partir de imagens psíquicas, o mundo só é possível na medida em que o ser humano é capaz de produzir sua imagem (JUNG, 2015). Jung em uma leitura metafísica compreende o homem como um ente cativo e confinado em sua psique, e essa impressão profunda de cativeiro gera a propensão de "admitir na psique a existência de coisas que desconhecemos e a que denominamos o inconsciente" (2015, p. 196). A existência psíquica, para o autor, seria a única que pode ser demonstrada diretamente, já que o mundo só passa a existir através da criação de sua imagem pelo ser psíquico.

Consideramos a matéria como uma realidade tangível e cognoscível. Entretanto, essa matéria é uma noção absolutamente metafísica, hipostasiada por cérebros não críticos. A matéria é uma hipótese. Quando se fala em matéria, está se criando, no fundo, um símbolo de algo que escapa ao conhecimento, e que tanto pode ser o espírito como qualquer outra coisa; pode ser inclusive o próprio Deus (p. 193). 


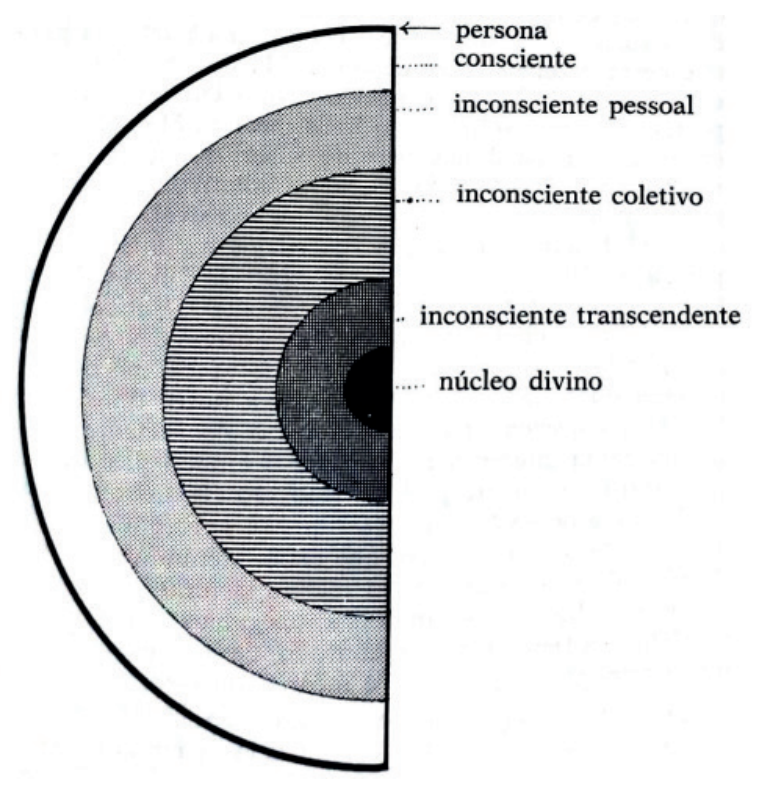

Figura 10 - Corte da célula psíquica proposto por Winckel.

Os exercícios cênicos apresentados nesta pesquisa se propuseram a pensar a práxis cênica a partir da consciência de que "o homem está contido na sua própria psique" (JUNG, 2015, p. 195). Esta forma de se pensar o fazer afastasse do construir e mostrar para a dimensão do revelar. Se

\begin{abstract}
formos capazes de conciliar-nos com o mistério de que o espírito é a vida do corpo, vista de dentro, e o corpo é revelação exterior da vida do espírito, se pudermos compreender que formam uma unidade e não uma dualidade, também compreenderemos que a tentativa de ultrapassar o atual grau de consciência, através do inconsciente, leva ao corpo e, inversamente, que o conhecimento do corpo não tolera uma filosofia que o negue em benefício de um puro espírito (JUNG in WURZBA, 2011, p. 91-92).
\end{abstract}

No exercício com o mito no âmbito da irracionalidade se busca revelar o espírito, as camadas profundas da psique, tanto do indivíduo como as de caráter coletivo. O corpo tornasse um corpo simbólico, mitopoético, parte da função transcendente.

$\mathrm{Na}$ função transcendente ou mitopoética, o inconsciente atua de modo compensatório em relação ao consciente. Por meio de sonhos, delírios, devaneios e pela imaginação ativa o inconsciente compensa a atitude consciente do indivíduo. 0 material tornado consciente pode ser resultante de experiências pessoais ou apresentar conteúdo de tonalidade impessoal, coletiva (BOECHAT, 2008).

Durante os dois exercícios cênicos citados, notamos um percurso instaurado pela memória, a entendendo dentro do desenho da imaginação proposto por Bachelard (1898 p. 17-18):

A imaginação não é, como sugere a etimologia, a faculdade de formar imagens da realidade; é a capacidade de formar imagens que ultrapassam a realidade, que cantam a realidade. É uma faculdade de sobre-humanidade. Um homem é um homem na porção em que é um super-homem. Deve-se definir o homem pelo conjunto das tendências que o impelem a ultrapassar a humana condição. Uma psicologia da mente em ação é automaticamente a psicologia de uma mente excepcional, a psicologia de uma mente tentada pela exceção: a imagem nova enxertada numa imagem antiga. A imaginação inventa mais que coisas e dramas; inventa a vida nova, inventa mente nova; abre olhos que têm novos tipos de visão. Verás se tiver visões.

Esse percurso se traçou da seguinte maneira: memória recente $\rightarrow$ memória antiga/infância $\rightarrow$ imagem arquetípica $\rightarrow$ arquétipo $\rightarrow$ modificação de gesto e da sensação tempo/espacial.

\section{1 - AS ÁGUAS DE SEBASTIAN}

Durante o exercício cênico Sebastian, solicitei ao ator Ian Habib que trabalhasse partir da memória do dia em que ocorreu uma modificação física importante em seu corpo. Pensando-se a processualidade do exercício, a resposta foi extremamente agressiva, contudo não gerou nenhum resultado estético satisfatório. $O$ ator se torturava em cena com um tecido imenso. Aos poucos, o processo psicofísico foi tornando-se mais denso e uma nova imagem se formou.

A imagem de um corpo exausto, agredido, envolto e sufocado por um cordão umbilical se formou em cena. A continuidade deste exercício culminou na imagem simbólica de uma espécie de caverna com poças de água e finalizou na sensação descrita pelo ator de um corpo em água. Estas imagens ocorriam na mente e no corpo do ator, se estruturavam num todo psicofísico.

Como já foi mencionado, Jung (2015) divide o inconsciente em dois níveis, o pessoal e o coletivo.

A camada pessoal termina com as recordações infantis mais remotas; o inconsciente coletivo, porém, contém o tempo pré-infantil, isto é, o resto da vida dos antepassados. As imagens das recordações do inconsciente coletivo são imagens não preenchidas, por serem forma não vividas pelo indivíduo. Quando porém a regressão da energia psíquica ultrapassa o próprio tempo da primeira infância, penetrando nas pegadas ou na herança da vida ancestral, aí despertam os quadros mitológicos: os arquétipos. 


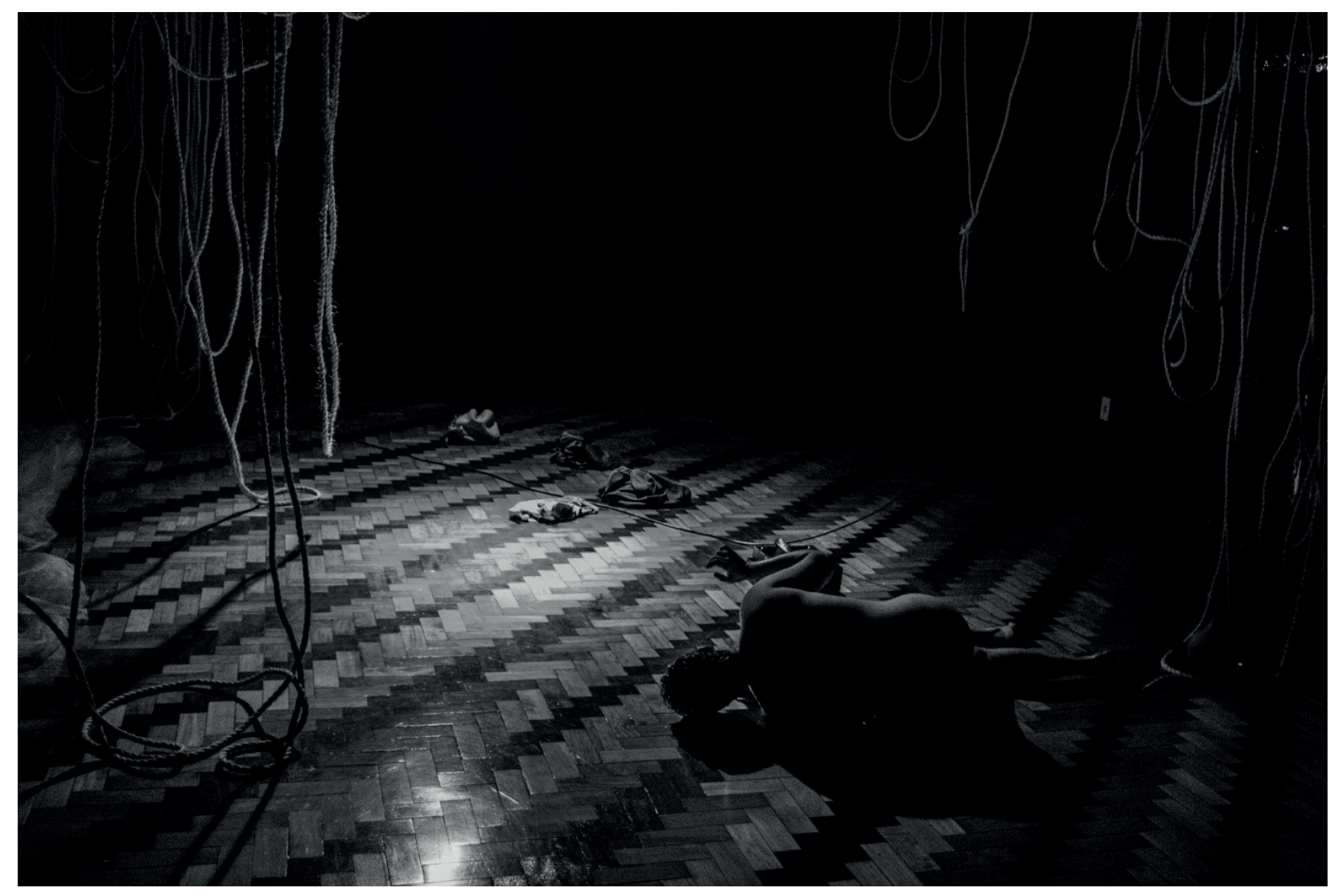

Figura 11 - 0 banho de purificação.

Abre-se então um mundo espiritual interior, de cuja existência nem sequer suspeitávamos (p.54-55).

Com o decorrer dos meses de ensaio, a imagem anteriormente citada assumiu outra dimensão de qualidade numinosa que pode ser notada pelos que presenciaram o ato e abaixo é relatada pelo ator Sebastian Habib:

Começou com a sensação de habitar um grande útero. Apagaram-se momentaneamente todas as conexões com o concreto. Havia apenas ecos e rastros de pensamentos e memórias completamente desordenados e caóticos, como que mergulhados no líquido uterino, dentro de uma placenta. Com acesso restrito, eu não conseguia mais acessá-los quando desejava. Nessa grande luta caí, amorteci e o cansaço me tomou. Deligaram-se várias válvulas. Senti um escuro momentâneo. Quando me levantei a luz me cegava. Não sabia mais o que estava fazendo, onde estava, quem era. A partir de então eu senti que eram esses mesmos ecos e rastros que me acessavam, me tomavam, desordenadamente e no tempo deles. Tornei-me um filtro. Já não ouvia ruídos vindos da rua e do público presente. Abriu-se uma fenda na realidade. Vivi em uma realidade outra, na qual as noções dos movimentos partiam de uma outra lógica temporal. A noção de começo e fim deixou de existir e eu deixei de seguir objetivamente a estrutura de ações proposta. Ao longo do processo senti que deixei de habitar meu corpo, um corpo unificado e centralizado, e me conectei a diversos outros corpos diferentes e não presentes na realidade concreta. Foi como dissipar e descentralizar minhas percepções. Havia um corpo material - meus músculos e ossos-realizando ações e movimentos, mas ele era guiado por diversos outros corpos. Em determinado momento senti uma ruptura ainda maior. Foi como se da dissipação na minha percepção eu conseguisse acessar algo ainda maior, uma consciência superior. Já não havia mais interno e externo. Eu era tudo e todos naquela sala. No momento final, em que era realizado um banho, o contato da água em meu corpo me trouxe um longo, profundo e desesperado choro. E eu entendi tudo. Era o momento de sair do grande útero. Meu renascimento.

\section{3 - CONCLUSÃO}

Após as experiências realizadas, atentei-me para a relação umbilical existente entre a formação do símbolo, a emoção e o afeto, a energia psíquica e a presença. Durante o exercício cênico Cura, eu pude notar, ao final dos ensaios, que em todos os momentos em que percebi a formação de uma imagem mental e deixei-me ser tomado pela mesma, a diretora Mayura Matos percebeu uma modificação na qualidade da presença cênica, assim 
como uma qualidade diferente de concentração. Dadas às devidas proporções, observei os mesmos resultados obtidos no espetáculo Sebastian.

O símbolo é a formulação exterior do arquétipo, a continuidade da imagem arquetípica. Jung (2008) assevera que os arquétipos são a um só tempo, imagem e emoção.

O arquétipo não é apenas a imagem em si, mas, ao mesmo tempo, dinamismo, que se manifesta na numinosidade, na força fascinante da imagem arquetípica. A realização e a assimilação do instinto acontecem [...] não por imersão na esfera instintiva, mas apenas pela assimilação da imagem que ao mesmo tempo também significa e evoca o instinto, mas de forma completamente diferente daquele em que o encontramos no nível biológico [...] ele (o instinto) tem dois aspectos; por um lado, é vivenciado como uma dinâmica fisiológica e, por outro, suas múltiplas formas entram na consciência como imagens e desenvolvem efeitos numinosos que estão ou parecem estar em oposição ao impulso fisiológico [...]. O arquétipo, como imagem do impulso, é psicologicamente uma meta espiritual ao qual insta a natureza do ser humano (JUNG apud JACOBI, 2016, p. 50, grifo do autor).

Nesse entrelaçamento de fisiologia e imaginário encontramos uma qualidade de presença cênica que dialoga com as propostas realizadas por Antonin Artaud, na qual o físico e o espiritual se congregam no exercício cênico. Christopher Innes (1992, p. 70), em seu estudo sobre o teatro sagrado nas vanguardas, traça comentários sobre estas relações nos escritos artaudianos:

Imágenes de energia en el inconsciente y crimen gratuito en la superfície de una presentación teatral evocan, se supone, un estado de espejo en la mente del espectador si se pueden proyectar con la violência necesaria; e este delirio será contagioso, exorcizando las pautas de conducta represiva de la sociedade en conjunto, por su presencia entre el minúsculo porcentaje de la problación que asiste al teatro de Artaud (analogia con la peste que en la confusa metáfora de Artaud es libertad espiritual), causando que todas las formas sociales se desintegren que cunda sin ratas, sin micróbios, sin contacto. La vinculación de lo físico y lo espiritual en esta metáfora es típica del enfoque de Artaud. Hay que imprimir la metafísica en la mente a través de la piel; la dinâmica de la consciencia está encarnada en ritmos escénicos, las armonías lineales de un cuadro afectan directamente al cérebro.

Nos experimentos realizados em sala de ensaio, percebeu-se que o corpo quando em estado de transe, no qual alcance qualidades profundas de concentração, adquire novas variedades de tônus, ritmos e movimentos, ao mesmo tempo em que ocasiona uma forte onda emocional e numinosa expressando-se como afeto. Acredito que esta seja a dimensão arquetípica do trabalho e nas vezes que esta foi alcançada, estabeleceu com os envolvidos no ato um circuito de comunicação irracional, na qual a comunicação se dava por via inconsciente.

Na psicologia junguiana há o que se denomina infecção psíquica. Nesta infecção há uma ligação real entre aquele que se revela e aquele que observa. Quando "as portas estiverem abertas, duas psiques estarão fluindo juntas. Poder-se-á falar num "encontro de almas"'" (HILLMAN, 1984, p. 19). A presença neste caso afastasse do corpo em movimento e variação energética e ocorre na dimensão inconsciente e arcaica acessada no encontro desnudado de dois seres.

Nesta infecção psíquica encontramos um tanto da asseveração grotowskiana de que o "a coisa mais importante é o encontro" (GROTOWSKI, 2011, p. 43). E que este encontro "resulta de uma fascinação. Ele implica uma luta, e também algo tão semelhante em profundidade que existe uma identificação entre os que tomam parte no encontro" (GROTOWSKI, 2011, p. 45).

\section{REFERÊNCIAS BIBLIOGRÁFICAS}

BACHELARD, Gaston. A áqua e os sonhos. Tradução: Antônio de Pádua Danesi. São Paulo: Martins Fontes, 1989.

BACHELARD, Gaston. A poética do devaneio. Tradução: Antônio de Pádua Danesi. São Paulo: Martins Fontes, 1988.

BAIOCCHI, Maura. Butoh: dança veredas d'alma. São Paulo: Palas Athenas, 1995.

BOECHAT, Walter. A mitopoese da psique: mito e individuação. Petrópolis: Vozes, 2008.

BARBA, Eugenio. A terra de cinzas e diamantes: minha aprendizagem na Polônia. Tradução: Patrícia Furtado de Mendonça. São Paulo: Perspectiva, 2006.

CAMPBELL, Joseph; MOYERS, Bill. o poder do mito. Tradução: Carlos Felipe Moisés. São Paulo: Palas Athenas, 1990. 
CUESTA, Jairo; SLOWIAK, James. Jerzy Grotowski. Tradução: Julia Barros. São Paulo: É Realizações, 2013.

COHEN, Renato. Work in progress na cena contemporânea: criação, encenação e recepção. São Paulo: Perspectiva, 1998.

DORST, Brigitte. Introdução. In JUNG, Carl Gustav. Espiritualidade e transcendência. Seleção e edição: Brigitte Dorst. Tradução da introdução: Nélio Schneider. Petrópolis: Vozes, 2015.

EDINGER, Edward F. Anatomia da psique: 0 simbolismo alquímico na psicoterapia. Tradução: Adail Ubirajara Sobral e Maria Stela Gonçalves. São Paulo: Cultrix, 2006.

ELIADE, Mircea. O Sagrado e o Profano. Tradução de PolaCivelli. São Paulo: Perspectiva, 2016.

FEINSTEIN, David; KRIPPNER; Stanley. Mitologia Pessoal: a psicologia evolutiva do self. Tradução: Teresinha Batista Santos. São Paulo: Cultrix, 1997.

FLASZEN, Ludwik; POLLASTRELLI, Carla (Orgs.). 0 Teatro Laboratório de Jerzy Grotowski 1959

- 1969. Tradução: Berenice Raulino. São Paulo: Perspectiva; Pontedera, IT: Fondazione Pontedera Teatro, 2011.

FRANZ, Marie-Louise von. Adivinhação e sincronicidade: a psicologia da probalidade significativa. Tradução: Álvaro Cabral. São Paulo: Cultrix, 1993.

GROTOWSKI, Jerzy. Para um teatro pobre. Tradução: Ivan Chagas. Brasília: Perspectiva; Pontedera, IT: Fondazione Pontedera Teatro, 2010.

HILLMAN, James. Uma busca interior em psicologia e religião. Tradução: Aracéli Martins Elman. São Paulo: Paulus, 1984.

HOLLIS, James. Mitologemas: encarnação do mundo invisível. São Paulo: Paulus, 2005.

INNES, Christopher. El teatro sagrado: el ritual y lavanguardia. Traducción: Juan José Utrilla. Cidade do México, MX: Fondo de cultura económica, 1992.

JACOBI, Jolande. Complexo, arquétipo e símbolo na psicologia de C. G. Jung. Tradução: Milton Camargo Mota. Petrópolis: Vozes, 2016.

JUNG, Carl G. A energia psíquica. Tradução:
Mateus Ramalho Rocha. Petrópolis: Vozes, 2015.

A natureza da psique. Tradução: Maria Luíza Appy. Petrópolis: Vozes, 2000a.

. Espiritualidade e transcendência.

Seleção e edição: Brigitte Dorst. Tradução da introdução: Nélio Schneider. Petrópolis: Vozes, 2015

. 0 espírito na arte e na cinência.

Tradução: Maria de Morais Barros. Petrópolis: Vozes, 2013b.

- homem e seus símbolos.

Tradução: Maria Lúcia Pinho. Rio de Janeiro: Nova Fronteira, 2008.

Os arquétipos e 0 inconsciente coletivo. Tradução: Maria Luíza Appy e Dora Mariana R. Ferreira da Silva. Petrópolis: Vozes, 2000b.

Psicologia e alquimia. Tradução:

Dora Mariana R. Ferreira da Silva. Petrópolis: Vozes, 2012a.

Psicologia e religião. Tradução: Matheus Ramalho Rocha. Petrópolis: Vozes, 2012b.

Sincronicidade. Tradução: Matheus Ramalho Rocha. Petrópolis: Vozes, 2014.

KAST, Verena. Sísifo: Vida, morte e renascimento através do arquétipo da repetição infinita. Tradução: Erlon José Paschoal. São Paulo: Cultrix, 2017.

LYRA, Luciana. Guerreiras e heroínas em processo: da artetnografia à metodologia em Artes Cênicas. 2010. Tese (Doutorado em Artes), Instituto de Artes, Universidade Estadual de Campinas (UNICAMP): Campinas-SP, 2011.

Mito Rasgado: Performance e cavalo marinho na cena in process. 2005. Dissertação (Mestrado em Artes). Instituto de Artes, UniversidadeEstadual de Campinas (UNICAMP): Campinas-SP, 2005.

MARTINS, Leda. Performances da oralitura: corpo, lugar da memória. Letras. Santa Maria, n. 26, p. 63-81, Jun., 2003.

MAUSS, Marcel. HUBERT, Henri. Sobre o sacrifício. São Paulo: Cosac Naify, 2005. 
MOTTA LIMA, Tatiana. Palavras praticadas: 0 percurso artístico de Jerzy Grotowski, 1959 1974. São Paulo: Perspectiva, 2012.

. Cantem, pode acontecer alguma

coisa": em torno dos cantos e do cantar nas investigações do Workcenterof Jerzy Grotowski and Thomas Richards. Revista Brasileira de Estudos da Presença. Porto Alegre, V. 3, n. 1, p. 220-240, Jan./Abr., 2013.

NUNES, Alexandre Silvia. Ator, sator, satori: Labor e torpor na arte de personificar. Goiania: Editora UFG, 2012.

Dioniso como método: teatro, mito e ritual no espetáculo NJILAS: Dance e Esqueça suas Dores. Urdimento. Florianópolis, V.2, n.27, p.21-35, Dez., 2016.

OTTO, Rudolf. 0 sagrado: os aspectos irracionais na noção do divino e sua relação com o racional. Tradução: Walter O. Schlupp. São Leopoldo: Sinodal/EST; Petrópolis: Vozes, 2007.

SALOMÃO, Eduardo Rizzatti. Exército encantado de São Sebastião: um estudo sobre a reelaboração do mito sebastianista na guerra do contestado (1912-1916). 2008. Dissertação (Mestrado em História Social), Universidade de Brasília: Brasília, 2008.

WINCKEL, Erna van de. Do inconsciente a Deus. Tradução: Benôni Lemos. São Paulo: Paulinas, 1985.

WURZBA, Lilian. A dança da alma: a dança e o sagrado, um gesto no caminho da individuação. In ZIMMERMANN, Elizabeth (Org.). Corpo e Individuação. Petrópolis: Vozes, 2011.

\section{SOBRE O AUTOR}

Saulo Vinícius Almeida é ator e diretor teatral, mestrando em Artes Cênicas (Pedagogia do Teatro - Formação do Artista Teatral) pela USP com o projeto "A experiência numinosa nas práticas formativas do ator". É graduado em Teatro UFRGS, onde atuou como bolsista no projeto "Percursos do drama brasileiro: narrativas, mitos e performances teatrais, de folguedos e reisados, na formação da dramaturgia", no qual estudou ao longo de três anos as relações entre mitologia, psique e a práxis cênica. Integra o Grupo de Estudos em Estética Contemporânea coordenado pelo prof. Dr. Ricardo Fabbrini, locado no Departamento de Filosofia da USP e é colaborador do LAt! - Laboratório de Atuação, coordenado pela Prof( Dr ( Alice Kiyomi Yagyu e locado na Escola de Comunicações e Artes da USP. Durante sua formação como artista-pesquisadorpedagogo, frequentou o bacharelado em Teatro (Interpretação Teatral) da UFMG. Seu interesse atual se encontra na zona fronteiriça entre a experiência do poético e a experiência do sagrado. 